\title{
残留応力と微小かたさの関係について*
}

\author{
平修 二** 吉 岡 靖 夫***

\section{On the Relation between Residual Stress and Micro Indentation Hardness}

\author{
by \\ Shuji TAIRA and Yasuo YoshiokA
}

(Faculty of Engineering, Kyoto University) (Musashi Institute of Technology)

In the present study, experiments were carried out to find the influence of stress on the micro-Vickers hardness, using carbon steel.

Mechanically applied stress, residual stresses due to heat treatment and cold-working were given to specimens. For measuring surface stress, the X-ray technique reported by Christenson and Rowland was employed. As an application of this experiment, the change in residual stress and hardness due to the aging at room temperature were measured. Experimental results were discussed from the standpoint of relief of stress due to indentation.

The results of experiments are summarized as follows :-

(1) Hardness increases proportionally to the magnitude of surface compressive stress and, on the contrary, inversely to tensile stress. A linear relationship holds between stress and hardness.

(2) The change in hardness due to cold-working is caused by residual stress and work hardening.

(3) The change in hardness of the quenched specimen due to aging, is influenced by the residual stress and the transformation of metal. Both hardness and residual compressive stress decrease until about ten days after quenching, and thereafter hardness increases gradually, while residual compressive stress maintains nearly a constant value except for a temporary increase at about 15 th days after quenching.

(Received Oct. 25, 1961)

\section{1. 緒}

著者のうちの一人は前にかたさ基準片に関する研究 において, 基準片表面の残留応力が変化すれば, 公称 かたさ值が変化することを明らかにし, 硬度測定に際 しては残留応力の存在はきわめて重要な因子となるこ とを指摘した。

かたさの定義は他の物理量のように明確なものでは なく，材料の試験および使用目的に応じた解积がなさ れており，したがってその定義の範囲も広範で, 降伏 強度, 引張強度, 塑性変形に対する抵抗, 耐摩耗性, 切削抵抗, 材料の均一性等材料の種々の性質の目安と

して使用されている。

特に硬度を用いての降伏強度の推定については, Tabor らはかたさ $H$ は降伏応力を $\sigma_{s}$ とするとさ， $H$ $=c \sigma_{s}$ なる関係で表わされることを示している。 $c$ は

\footnotetext{
* 原稿受付 昭和 36 年 10 月 25 日, 第 5 回材料試験連合講演会にて 講演 (昭36.9)

** 正員 京都大学工学部

****正員武蔵工業大学
}

ブリネルかたさの場合 $2 \cdot 9$, ビッカースかたさのとさ $3 \cdot 2$ であり, 引張試験を行なわないで材料の降伏強度 を推定することができると述べている，しかし，测定 する試料に残留応力が存在すれば，降伏強度は変化す ることが考えられ，また，上述のようにかたさは残留 応力により変化することが当然予期される。この種の 問題に関しては，G. Sines と R. Carlson および A. Dervishyan がブリネルかたさを引張りまたは圧縮応 力を加えたときに測定しているが，材料の有する真の 応力に対応するかたさ変化を測定した例はほとんど見 当らない.このことは, 従来の応力測定法が単に付加 応力のみの測定しかできなかったことに原因する。そ こで著者らは，かたさを測定するとともにX線による 応力測定法を用い, 試料表面の応力を測定して, 応力 とかたさとの関係についての実験および考察を行なっ た。

\section{2. 実験について}

\section{（I）実験方法}


かたさはマイクロビッカース硬度計を用いて測定を 行なった，応力を变化させる手段としては単純引張り および圧縮が好ましいが, 微小硬度計に取り付けて測 定する関係上大きさが限定されるので，ここでは曲げ モーメントを与えて試料表面に引張応力を与えるよう にした，装置の概要を Fig. 1 に示す，応力は締付け ボルトを締めることによって種々变化させる。

圧縮応力は上記の装置では与えられず, また, 挫屈 等のために硬度計を破損する危険もあるので, 試料表 面の圧縮残留応力分布を場所により变化させて, 各部 分の硬度を測定することにした．その方法としては，

Fig. 2 のような偏心リングを造って, 変態点以下の温 度より水焼入れをして, 熱応力による圧縮残留応力を 生ぜしめる.リングの幅の狭い部分では, 水冷の際内 部まで冷却が早くいきわたるので残留応力はほとんど 発生しない. しかし幅の広い部分では冷却の際の内外 の温度差のため表面に圧縮残留応力が発生する。した がって,リングの幅の変化と残留応力の変化とは対応 するので, 各部の残留応力とかたさを測定した.

以上二つの実験は, 弾性限度内の応力によるかたさ 变化を測定するものであるが, 次に塑性加工を行なっ た際に生ずる残留応力とそれに伴うかたさ变化につい ての実験を行なった。この実験では曲げにより板材の 表と裏にそれぞれ圧縮と引張りの等量の応力を加え, 付加応力が材料の降伏応力を越えると, それぞれ引張 りおよび圧縮の残留応力が表と裏に生ずる。この場合 の残留応力の变化に伴うかたさ変化を測定した.

最後に, 以上の実験の一つの応用として焼入れした 鋼の残留応力とかたさの経日变化を測定した.

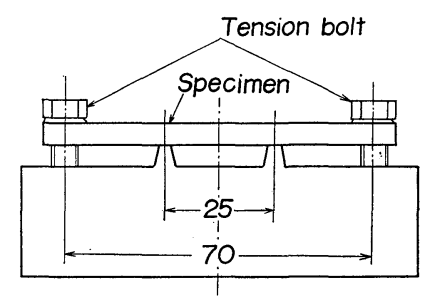

Fig. 1 Testing apparatus

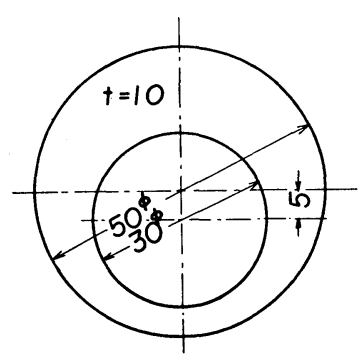

Fig. 2 Dimension of eccentric ring

\section{(II) 実験材料}

実験に使用した材料はすべて炭素鋼を使用した，最 初の実験に使用した試験片は $0.44 \%$ 炭素鋼であり, $870^{\circ} \mathrm{C}$ で 1 時間焼なまし後炉中冷却したもの，および $870^{\circ} \mathrm{C}$ より水焼入れ後, $250^{\circ} \mathrm{C}$ に 1 時間保持した後, 空中冷却を行なった焼もどし材である.

偏心リングに対する実験には $500^{\circ} \mathrm{C} よ り$ 水焼入れを 行なった SK 4 材を用いた.

残留応力およびかたさの経日变化に関する実験に使 用した材料は， $870^{\circ} \mathrm{C} よ り$ 水焼入れを施した $0.68 \%$ 炭素鋼である。

\section{(III) かたさ測定について}

$\mathrm{X}$ 線によって表面応力を測定し, 得られた応力の大 きさ扎よび種類とかたさの関係を求めるのが本研究の 主目的であるため，できうるかぎり試験片表面からの 圧子侵入深さが小さい測定法を用いることが好ましい． また, 応力を变化させる方法として曲げによる方法を 採用しているため, 試験片内部に応力こう配が生ずる ことが考えられるので, 本実験においては微小硬度計 すなわちマイクロビッカース硬度計を使用した。

微小かたさについては, 測定精度, ばらつき, 荷重 とかたさの関係等，いろいろな問題があり，特に測定 荷重の選定は求めるかたさ值に大きな影響を与えるこ とが考えられるゆえ，あらかじめ焼なまし材について 荷重一かたさ曲線を求めて本実験における荷重の大き さを決定した. Fig. 3 はその結果を示したものである. $500 \mathrm{~g}$ 以上の荷重に対してほぼ一定かたさを示すこと が認められるゆえ，本実験にては荷重を $1000 \mathrm{~g}$ とし た. 測定した材料の中のいちばんやわらかいもので圧 痕の対角線は約 $120 \mu$, 最もかたいもので約 $43 \mu$ であ った。

\section{(IV) 応力測定について}

本実験に用いた応力測定方法はすべて X 線による 方法を採用した，X線による応力測定法はすでに Glocker らにより確立されて以来, 今日まで唯一の非 破壊的, 局所的な表面応力の測定法として広く用いら れてきた。すなわち, 被測定材の表面に垂直, および

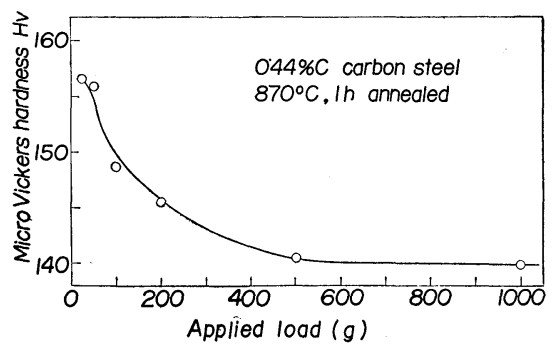

Fig. 3 Variation of hardness with applied load for carbon steel 
$45^{\circ}$ 方向より特性 $\mathrm{X}$ 線を入射して得られる回折 $\mathrm{X}$ 線を フィルムまたは計数管で受け, 回折強度分布曲線を求 めて(フィルム法の場合はミクロフオトメーターによ り黒化度の自記曲線を求める）その回折強度最大の位 置を測定して次式により応力を算出する.

$$
\sigma=\frac{E}{1+\nu} \cdot \frac{1}{\sin ^{2} \phi} \cdot \frac{d_{\psi}-d_{1}}{d_{0}}
$$

ここで $\phi=\phi_{0}+\eta て ゙ \phi_{0}$ は試料法線に対してのX線 入射角, $\eta=90^{\circ}-\theta$ で $\theta$ は Bragg 角を表わす.

$d_{\perp}$ : 試料に対してX 線を垂直に入射したときの格子 面間隔

$d_{\psi}: \mathrm{X}$ 線を試料法線に対して $\phi_{0}$ だけ傾けて入射さ せたときの格子面間隔

$d_{0}$ : 試料の無灾力状態のときの格子面間隔

しかし最近 Christenson と Rowland は上述の

Glocker による方法を発展させ $(1)$ 式を次のように変 形した.

$$
d_{\psi}=\left[\frac{1+\nu}{E} \cdot d_{0} \sigma\right] \sin ^{2} \psi+d_{0}\left[1-\frac{\nu \sigma}{E}\right]
$$

この式は， $d_{\psi}$ と $\sin ^{2} \phi$ との関係が一次的であること， また， $\sigma$ の值のいかんにかかわらず $\sin ^{2} \psi=\nu / 1+\nu に$ おいて, $d_{\phi}=d_{0}$ となる。したがって, 実際 X線応力測 定にあたって $\psi$ を，三，三变化せしめて，それぞれの 角度に対応する $d_{\psi}$ を求めれば，もしその測定值が正 しければ， $d_{\psi}-\sin ^{2} \psi$ の関係は完全に直線になり，か つ $\sin ^{2} \phi=\nu / 1+\nu$ なる点で $d_{0}$ 一定なる横軸に平行な 直線と交わるはずである。

すなわち，以上のように Glocker 法に比べて， ChristensonとRowland の方法は少し手数を要する が, より精度の高い測定值が得られるものと考えられ るゆえ，本実験においては，もっぱらこの Christenson と Rowland の方法を採用して応力を測定した。

用いたX線回折装置はガイガー計数管を用いた自動 記録式ひずみ測定用のものであり， $\mathrm{Cr} の \mathrm{~K} \alpha$ 線を用 い, 垂直および二，三傾斜角を变化せしめて入射して 得られる (211) 面回折線の回折強度曲線より応力を決 定した。

また，実験の一部，すなわち残留応力分布の变化と かたさの関係に用いた偏心リングには，特に照射面積 が限定されるためにフィルム法を採用して，X線ビー ムの直径を $1 \mathrm{~mm} \phi$ とした。

\section{3. 実 験 結 果}

Fig. 1 に示す装置によって弾性限度内の応力を与え た場合のかたさと応力との関係のうち，焼なまし材に ついての結果を Fig. 4 に示す. 引張応力が材料に加 わるとビッカースかたさはほぼ直線的に減少していく ことがわかる。ブリネルかたさについては Sines こ の実験結果があるが，その傾向は今回の実験と同じで
直線的な減少を示している。このかたさ減少に伴い Fig. 4 のように，付加応力の方向と一致した対角線の 長さを $b$, 応力方向と $90^{\circ}$ の方向の圧痕対角線を $a$ と して, 压痕対角線比 $a / b$ を求めると, この $a / b$ も引 張応力の増加に伴い减少していく．すなわち $b$ の増加 は $a$ の増加より大きいことを示している。

この材料の引張試験より得た降伏応力は約 $32 \mathrm{~kg} /$ $\mathrm{mm}^{2}$ であった．表面の応力が $0 \mathrm{~kg} / \mathrm{mm}^{2}$ の際のかた さは143であるから，前述の Tabor の式に代入する と $c=4 \cdot 4$ となる.

次に Fig. 5 に同じ実験を, 焼入れ後焼もどしを行 なった材料について行なった結果を示す。焼なまし材 と同じく, 引張応力の増加にしたがってかたさはおお よそ直線的に減少していく.

以上の実験は外部から応力を与えたとさのかたさ変 化であるが, 試料の残留応力の変化によっても同じ変 化が起こると考え，偏心リングによる実験を行なった。

残留応力およびかたさを測定した結果を Fig. 6 に示 す、リングの幅の最も狭い部分では, 残留応力はほと んどないが，いちばん幅の広い場所では約 $15 \mathrm{~kg} / \mathrm{mm}^{2}$ 程度の圧縮残留応力が生じている. そうして幅の増加 とともにほぼ直線的に残留応力は増加している。これ に対してかたさも圧縮残留応力の増加とともに増加し ている。したがって前の実験と，この実験から弾性限

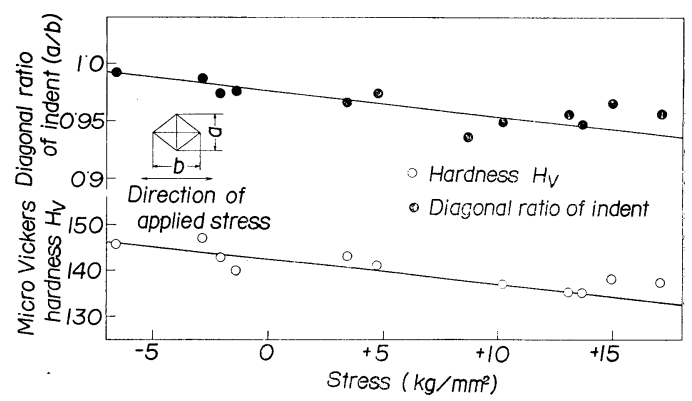

Fig. 4 Stress-hardness and diagonal ratio of indent for the annealed specimen $(0 \cdot 44 \% \mathrm{C})$

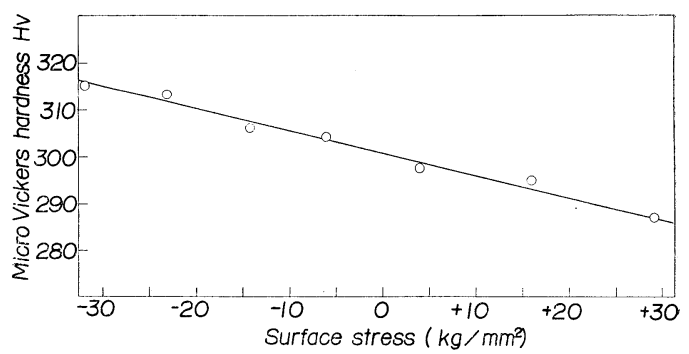

Fig. 5 Stress-hardness relation for the tempered $\left(250^{\circ} \mathrm{C}, 1 \mathrm{~h}\right)$ specimen $(0.44$ $\%$ C) 


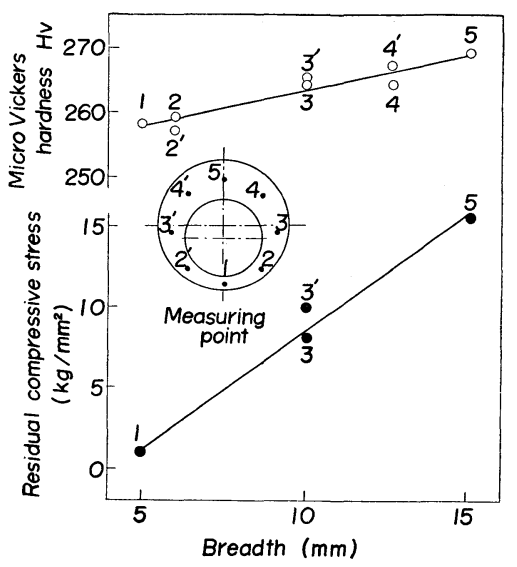

Fig. 6 Breadth of eccentric ring-residual stress and hardness relation

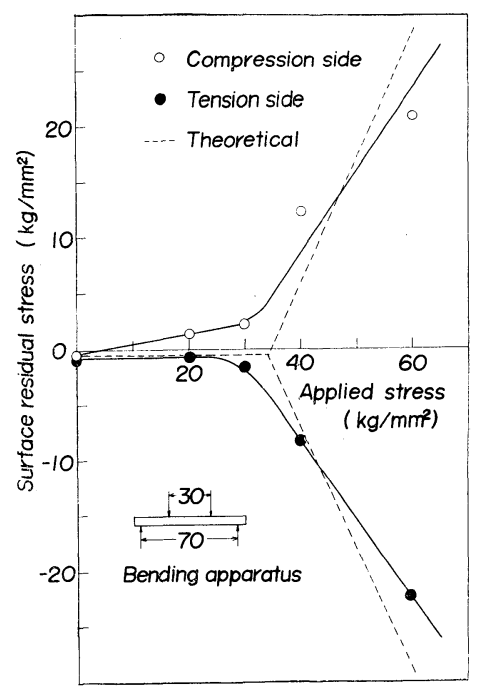

Fig. 7 Change in surface residual stress of bending bar after bending (annealed specimen)

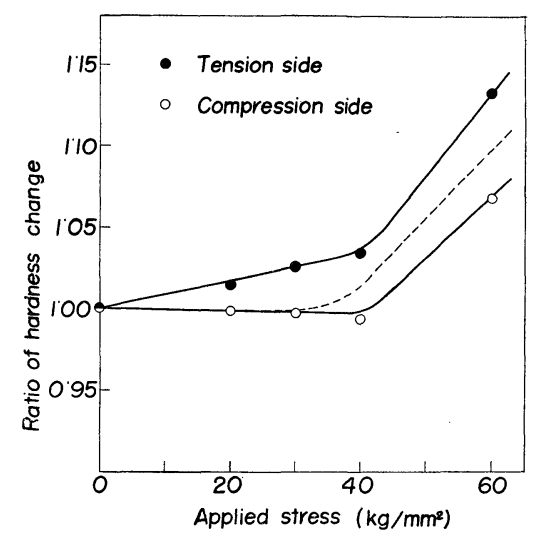

Fig. 8 Ratio of hardness change on the surface of bending bar after bending (annealed specimen)
度内の引張応力はかたさを減少させ, 圧縮応力はかた さを増加させるといえる。

次に塑性域の応力を与えた際の実験結果を Fig. 7, 8 に示す. Fig. 7 は曲げ試験を行なった際に板の両面 (引張側と圧縮側)に生じた残留応力と付加応力の関係 を示したものである．曲げを加えると板の支点間の中 心の両面には符号が逆で, 大きさの等しい応力が生ず る. 弾性限度内では, 付加応力を除荷したとき残留応 力は理論的には発生せず, 付加応力が降伏応力を越え ると, ほぼ付加応力から降伏応力を差し引いただけの 残留応力が試料表面に生ずる．Fig. 7 では点線で示し たのが理論的な応力变化である. 付加応力が $40 \mathrm{~kg} /$ $\mathrm{mm}^{2}$ までは測定值はほとんど理論值に等しいが，付 加応力が $60 \mathrm{~kg} / \mathrm{mm}^{2}$ では, 引張り, 圧縮の両残留応 力とも, 理論值より小さい值である。このときのかた さ变化比を Fig. 8 に示すが, 引張側, すなわち圧縮 の残留応力が生じた側のかたさのほうが，圧縮側，す なわち引張残留応力の生じた側のかたさより大きく变 化している.

最後に焼入れ後の経日変化についての結果を Fig. 9 に示す. 残留応力は焼入れ直後には圧縮で約 $57 \mathrm{~kg} /$ $\mathrm{mm}^{2}$ であったものが，徐々に減少していき，10日後 には約 $32 \mathrm{~kg} / \mathrm{mm}^{2}$ 程度になる。しかし，15日ころで は圧縮側にいったん増加するが，20日以後はまた減少 してある一定の值になる傾向がある。この残留応力の 変化過程は, 平, 北野および平, 村上によって求めら れた結果とほぼ同じ傾向である。かたさ変化について は, 焼入れ直後より10日ころまでは, 残留応力の減少 とともにかたさも減少するが，そこを境としてその後

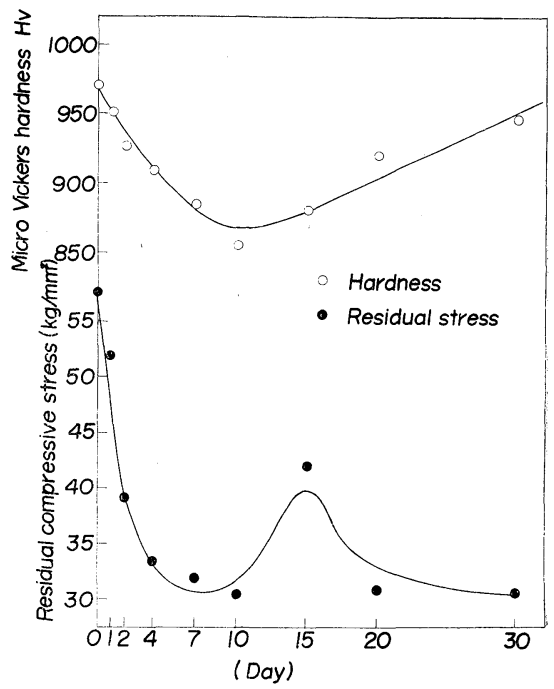

Fig. 9 Change in hardness and residual stress due to aging for the quenched specimen $(0 \cdot 68 \% \mathrm{C})$ 
は增加の傾向をたどり，30日後では焼入れ直後のかた さとほとんど同じ值を示す。

\section{4. 考察}

まず, 最初に引張応力によりかたさが減少し, 圧縮 応力によってかたさが増加する現象について考察する. この考察は定量的に行なうのが理想であるが, 三次元 問題であるので，現在完全解を得るのは困難であるの で定性的な考察にとどめる. Fig. 10 に压子を押し込 んだときの圧子近辺の状態を示す，Hillによれば，図 中のハッチを入れた部分が塑性変形した部分である。

普通ビッカースかたさを測定するには，圧痕の対角線 を測定してこれより圧痕表面積を計算して, これと荷 重よりかたさ $H$ を求める. そこで Fig. 10 の圧子断面 は一つの圧子の陵線を表わしているものと考え, 図の 矢印の方向に引張応力が加わっているものとする. 圧 子を試料に押し込んだことにより, 試料の表面近傍は 局部的に二つに分けられたものと考える. 四では OB の部分で二つに分けられOの位置はAに移動したもの とする。このとき応力は圧子により解放されAの位置 は圧子陵線より離れ外側へ移動し図中に点線で示した $\mathrm{OA}^{\prime}$ が新しい压痕の陵線の位置となる。したがって, ビッカースかたさは, 压痕対角線が大きくなるので減 少する。逆に圧縮応力が存在すれば， $\mathrm{A}^{\prime}$ の位置は $\mathrm{A}$ 上 り内側に向かうゅえ，かたさは增加する。

以上の考察は応力が加わる方向に圧子の陵線の一つ が一致した面について考えたものである。一方, 応力 方向に直角な方向の圧子陵線について考えると, 応力 方向と一致した圧子陵線が試料より離れるために, こ の方向の圧子陵線付近に荷重が集中するため, この方 向に塑性変形がさらに起こり, 压痕対角線にある程度 の增加が起こる。ゆえに压痕対角線は付加応力が一軸 であっても, 縦, 横とも無応力の場合よりも引張応力 の存在のときには増加する。

上記の考察は単に圧子の押し込久による応力の解放 という見地から定性的に行なったものであるが，押し 込みかたさでは Tabor らの述べるように降伏強度と の密接な関係があるから，次にこの点から測定值に対 する検討を行なう。

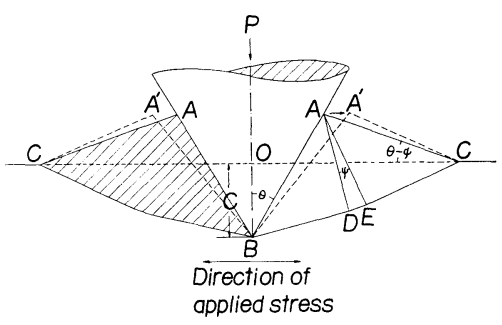

Fig. 10 Plastic deformation area by indenter
試料に引張応力が作用していれば, その応力方向の 引張降伏応力は $\left(\sigma_{s}-\sigma\right)$ である. したがってこの降伏 応力をかたさ試験で推定するのであれば $H=c\left(\sigma_{s}-\sigma\right)$ とならなければならない.しかし Fig. 4 の実験例で 示すように, 引張応力が $15 \mathrm{~kg} / \mathrm{mm}^{2}$ の際のかたさは 134 であり, 実験結果の項で述べた, $\sigma_{s}=32 \mathrm{~kg} / \mathrm{mm}^{2}$, $c=4 \cdot 4$ を用いて計算するとき， $H=4 \cdot 4(32-15)=75$ となるのと大きな開きがある。このことは, かたさ試 験によって得られる降伏応力は, 材料の 3 軸方向の值 であり, 単に一軸方向のみの降伏応力が变化しても, その変化は Tabor の式からは求められない.このこ とから残留応力が試料にある場合には降伏強度の推定 には，はなはだしい誤差を生ずることになるのでここ の点に対する注意が必要である。

以上は弾性限度内の応力が加わった場合のかたさ変 化に対する考察であるが, 次に塑性加工によるかたさ 変化について述べる．Fig. 8に見られるように，圧縮， 引張りの残留応力が生じても加工硬化のため, 降伏点 以上ではかたさが增加しているが, 引張りの残留応力 の生じた側のかたさ增加が圧縮残留応力の生じた側の かたさ增加より少ないのは, 弾性限度内のかたさ变化 と同じ理由で引張残留応力が生ずれば, 真の加工硬化 より引張応力による変化が差し引かれるためと考える. また，圧縮残留応力が生ずれば，加工による硬化に， 圧縮応力による変化が重畳してさらにかたくなるもの と考える. すなわち Fig. 8 の点線で示した曲線は, 加工硬化による值と仮定し, 実測值はこれに残留応力 の影響があるものと考える。このように弾性限度内の 応力によるかたさ変化に対して行なった考察を塑性加 工の場合にも拡張して解釈できる。

ただし, Fig. 8 の点線は説明上仮定したものであり， 実際はこれとは異なることも考えられるが, 機構の説 明という点では無理はないものと考える.

このような塑性加工においてもかたさは残留応力の 影響を受ける.工業製品, 特にショットピーニングや 表面ロール, 高周波焼入等により表面硬化した部品で は，普通表面に大きな圧縮残留応力を生ずる。このよ うな製品が使用中になんらかの原因によって残留応力 が減少すれば，かたさもそれに対応して減少するから， 初期のかたさをいつまで保持するかは疑問である。し たがって, 目標とするかたさは, 残留応力の变化によ る減少を見込んだ值として考える必要がある。

Fig. 9 の焼入れ材の経日変化については, 残留応力 が10日目ころまで減少していくのは, 安定化一の移行 として, 表面から中心部への応力分布のこう配が急で あったものが徐々にゆるやかになり, 表面の応力は減 少していくものと考える。しかし焼入れ後15日目くら いになると，焼入れの際に残っていた残留オーステナ 
イトがマルテンサイト化を始める。その変化は表面よ り徐々に内部に向かって進行していく，マルテンサイ ト化が起これば試料は膨張するため15日ころ，いった ん圧縮残留応力が増加する。しかし，それ以後では応 力し緩が起こって残留応力はある一定の值に減少する。 かたさのほうは, 最初, 焼入れ後より10日目ころま では圧縮残留応力の減少とともにかたさも減少してい くのであるが，15日目ころより表面にマルテンサイト が生成を始めるので，かたさは增加を始める。残留応 力は20日目ころから減少するが，マルテンサイト化は 続いて起こっているので，かたさは增加の傾向を示す のである。しかし，この増加もある量のマルテンサイ トができてしまえば，飽和して一定の值になるものと 考える.この考察は組織変化を観察していないので推 論であるが，残留応力とかたさの両者から上の上うな 説明をして無理はないものと考える。この例のように 焼入れをして残留応力分布や組織が不安定な材料では かたさ変化は, 残留応力および組織の変化に依存する. その変化過程は復雑であるが, 両者の変化を知ること によってかたさ変化の様相が判明する.

\section{5. 結 論}

炭素鋼の応力によるかたさ変化を測定した結果, 次 の結論を得た。
（1）引張応力はかたさを減小させ，压縮応力はか たさを增加させ，応力とかたさとの間には直線関係が ある。

（2）Taborの式による降伏強度の推定においては, ある方向に応力が存在して, その方向における降伏強

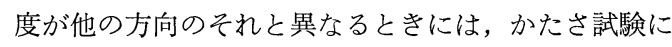
よって降伏応力を推定すると，大きな誤差をもちやす く，降伏強度の推定は危険である。

（3）塑性加工によるかたさ变化は，加工硬化と残 留応力によるかたさ变化が重畳したものである.

（4）焼入れによって起こるかたさの経日変化は残 留応力と組織の両方の変化が組み合ったものである.

\section{参 考 文 献}
1) 吉岡, 材料陚験, 11, 103，227 (1962)
2) D. Tabor, Proc. Roy. Soc., A. 192, 247 (1948)
3) G. Sines and R. Carlson, ASTM Bulletin, No. 180, 35 (Feb. 1952)
4) A. Dervishyan, ASTM Bulletin, No. 215, 71 (July, 1956)
5) R. Glocker and E. Osswald, Z. Techn. Phys., 16, 237 (1935)
6) A.L. Christenson and E.S. Rowland, Trans. ASM, 45, 638 (1952)
7) 平, 北野, 材料試験, $7,61,552$ (1958)
8) 平, 村上, 材料試験, 7, 62, 591 (1958)
9) R. Hill, 塑性学, 211 (1954)

(378頁より)

\section{土木 建 築 材 料}

\section{高強度鋼構造材の経済性 (Economy of High}

Strength Structural Members) Geerhard Haaijer, Proc. ASCE, Vol. 87, No. ST8, pp. 1-23 (Dec. 1961)

最近の高強度鋼は, 一般構造用炭素鋼に比較して, 降伏点強度の上年の割に価格の増加は少ない．この点 に着目して，橋梁および建築物に使用される形式の部 材断面において，いかに高強度鋼を使用すれば経済的 で, かつ軽量化できるかを, 降伏点, 弾性係数, 鋼単 価などを考慮して理論的に解析し，その結果を各種の I 形断面材に適用して, 一般構造用の ASTM A-7 鋼 を用いる場合に対して鋼重と材料費の比較検討を試み たものである。

考えた鋼材は，構造用炭素鋼 ASTM A7, A36; 高強度鋼: ASTM A440, A441 USS COR-TEN; 合金鋼 : USS “T-1” type A, USS “T-1”である.
結論として, 引張材では板の溶接断面の場合, “ $\mathrm{T}$ -1 ”鋼によると $67 \%$ の鋼重軽減, “T-1” type A 鋼板によると $32 \%$ の材料費節減, 圧延型鋼の場合, $\mathrm{A} 440$ 鋼では $24 \%$ の材料費節約となる。また I 型断面 はり(梁)の場合は，ウェブ高さと厚さの比を等しくす ると，圧延材では “T-1”鋼で最大の軽量化 (52\%) が得られ，材料費節减はA 440 鋼で $12 \%$ となった。 ウ エブ高さと厚さの比を局部座屈で押えると, 短スパン のときは鋼重軽減に材料費增大が伴うが, 長スパンと なると材料費減少が目だつ。ウェブに低強度鋼，フラ ンジに高強度鋼を使用した溶接混成断面はりは, 鋼重, 材料費とも顕著な減少を示した。たとえば，A-7 鋼の ウエブと “T-1” type A 鋼のフランジよりなる混成 材は $15 \%$ の材料費節減と， $37 \%$ の軽量化を示した。

(西村 昭) 